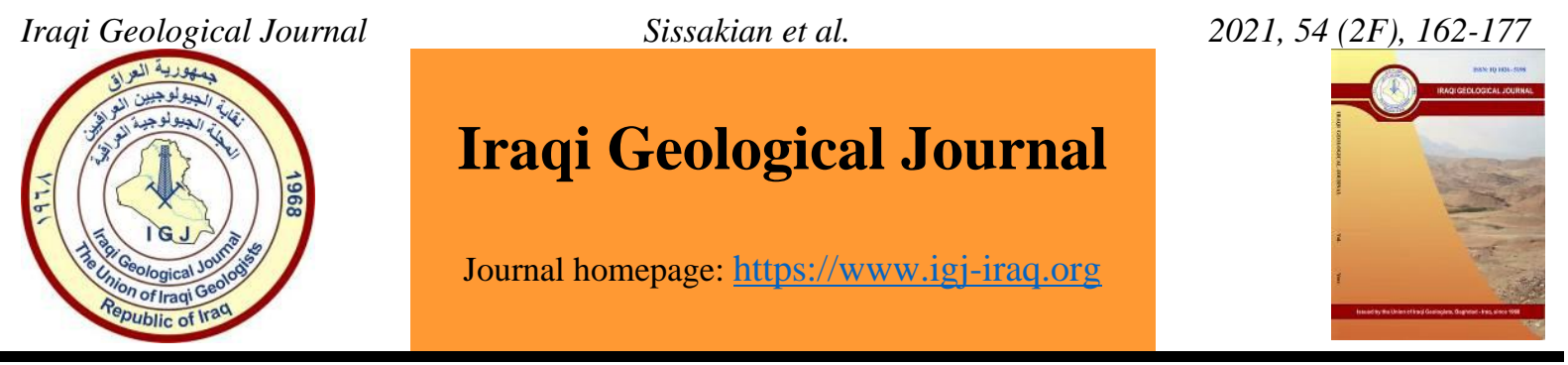

\title{
Shakrook Anticline, a Very Complicated Structural Form, North Iraq, Kurdistan Region
}

\author{
Varoujan K. Sissakian ${ }^{1, *}$, Ala A. Ghafur ${ }^{1}$, Hawkar A. Abdulhaq ${ }^{2}$ and Hassan O. Omer ${ }^{1}$ \\ 1 Department of Natural Resources Engineering and Management, School of Science and Engineering, University of \\ Kurdistan Hewler, Iraq \\ 2 Department of Civil Engineering, School of Science and Engineering, University of Kurdistan Hewler, Iraq \\ * Correspondence: f.khajeek@ukh.edu.krd
}

Received: 8 July 2021; Accepted: 21 September 2021; Published: 31 December 2021

\begin{abstract}
The Shakrook anticline has very a complicated structural form, this is attributed to three thrust faults, and the presence of four anticlinal axes with the main anticlinal body. The most northwest existing anticline is called in the current study the Sisawa anticline, the main two anticlines are called the Shakrook East and Shakrook West, whereas the fourth one is called the Biluk anticline it is developed along the southwestern limb of the Shakrook East anticline. The exposed rocks in the Shakrook anticline range from Upper Jurassic to the Paleogene age. The bulk of the main Shakrook anticline is formed by the Bekhme Formation (Upper Cretaceous age), whereas the bulk of the Sisawa anticline is formed of the Shiranish Formation (Upper Cretaceous age) with Paleogene and Neogene aged rocks. Geological maps and high-quality satellite images were used to elucidate the complex structural form of the Shakrook anticline. The updated geological map is quite different from those existing geological maps. A field investigation was carried out to check the interpreted data and to implement photography to the interested structural and geomorphological forms. Different geomorphological forms also were interpreted; they all refer to the lateral growth of the Shakrook anticline.
\end{abstract}

Keywords: Shakrook anticline; Thrust fault; Lateral growth; Wine glass; Cretaceous

\section{Introduction}

The Shakrook anticline exhibits very complicated structural form that is quite different from the existing anticlines in near surroundings, and it is oriented in a NW - SE trend. The Iraqi Kurdistan Region (IKR) is considered as tectonically an active area, it forms the northeastern part of the Arabian Plate (Berberian, 1993, Blanc et al., 2003, Bennett et al., 2005, Ramsey et al., 2008, Ghafur et al., 2019, Sissakian et al., 2020). The anticlines in the region are developed due to collision of the Arabian Plate with the Eurasian (Iranian) Plate, forming a convergent tectonic plate boundary (Alavi, 2004, Allen et al., 2004). According to Burbank and Anderson, (2001); Blanc et al., (2003); Fossen, (2010), some anticlines can exhibit anomalous structural shapes due to many reasons; among them are: overturning of the limbs, thrusting of the anticline over an adjacent anticline or even one limb over the other, enechelon plunging, being of multi-domes, extensive erosional forms, and due to exposure of different rock types with different competencies. The Shakrook anticline is one of those anticlines which has an

DOI: $10.46717 /$ igj.54.2F.14ms-2021-12-31 
abnormal structural shape. The activation of the pre-existing basement faults has strongly affected the geometric and kinematic evolution of the Zagros Fold-Thrust Belt (ZFTB), therefore variations in the sediment type, and their distribution were caused by those faults. It is worth mentioning that much of the sedimentary cover of the ZFTB was deformed by those faults, but the basement was not influenced (Le Garzica et al., 2017), because those faults do not reach the basement. Moreover, shortening occurred in the basement and sedimentary cover below these detachments due to inversion of pre-existing normal faults (Sepher and Cosgrove, 2004). The High Folded Zone (HFZ) at the IKR is a part of the ZFTB, whereas the Zagros Suture Zone that is in the northeastern part of the IKR, still shows a representative segment for a significant episode that witnesses the convergence history of the Arabian and Eurasian plates' collision (Al-Qayim et al., 2012). The HFZ is characterized by long and narrow anticlines separated by wide and shallow synclines (Jassim and Goff, 2006). One of the main characteristics of the developed anticlines at the IKR within the HFZ is the lateral growth; this is attributed to the tectonic activity of the region due to the collision of both mentioned plates (Berberian, 1993; Blanc et al., 2003; Bennett et al., 2005). The compressional forces exerted by the collision of the two plates have also developed regional thrust faults and different types of other faults; some of them are few kilometers in length, the main trend of the thrust faults is NW - SE, whereas the other faults are oriented mainly in NE - SW trend (Sissakian and Fouad, 2014, and 2015). The ZFTB, which was developed from deformation caused by Neogene continental collision between the Arabian and Eurasian plates represents one of the best examples for active orogens in the world (e.g., Falcon, 1974; Şengör and Kidd, 1979; Berberian and King, 1981, and Stoneley, 1981). The convergence process of the collision between the Arabian and Eurasian plates is still an ongoing process and has governed the geomorphologic evolution of the IKR by the lateral growth of folds, and the development of different geomorphic features. The lateral growth accompanied with the exerted forces due to the collision have deformed the normal shapes of the anticlines giving to many of those anticlines anomalous shapes by forming enechelon plunges (Campbell, 1958), swinging of the fold axes and developing of hanging synclines (Sissakian and Fouad, 2015). Different geomorphological and structural forms along many anticlines in the IKR indicate that the lateral growth of the anticlines is still active (Ghafur et al., 2019, Sissakian et al., 2020). The location of the Shakrook anticline is in the eastern part of the IKR, about $80 \mathrm{~km}$ northeast of Erbil city (Fig.1).

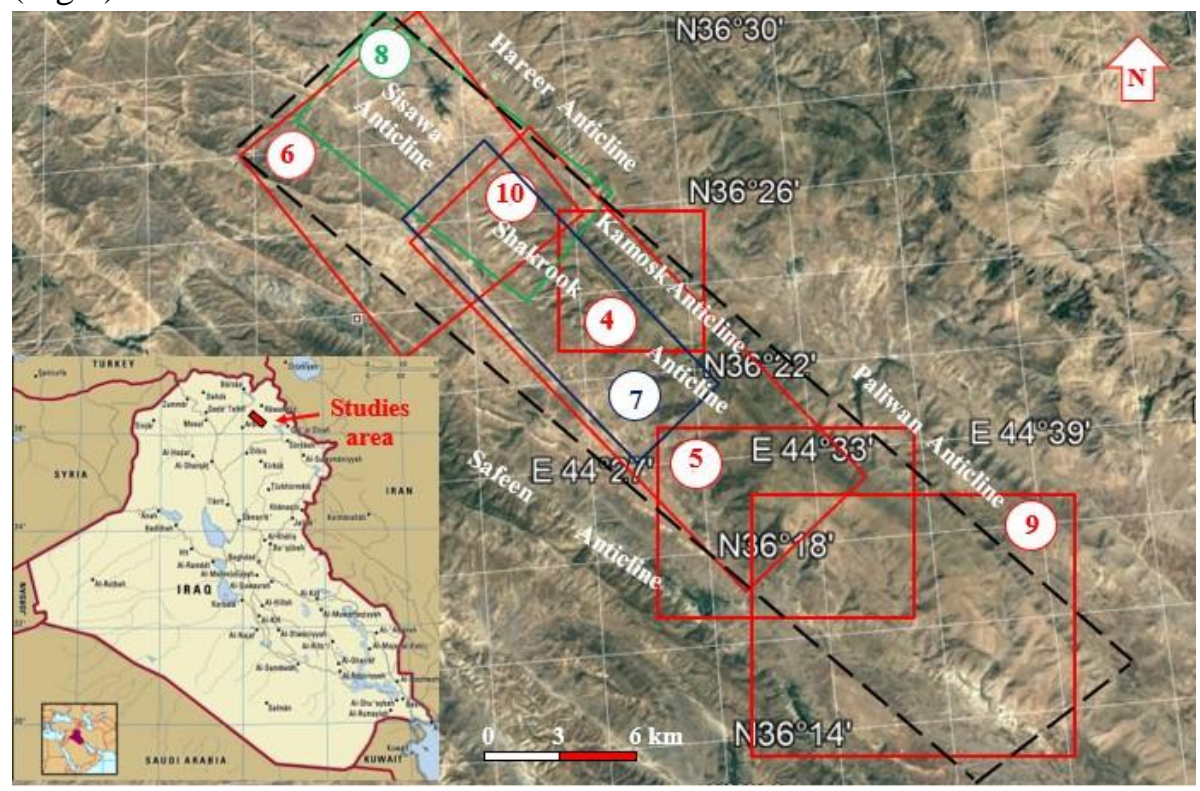

Fig. 1. Satellite image showing Shakrook anticline with locations of the presented images in the text with their serial numbers 
To the north of the Shakrook anticline, Hareer, Balisan and Kamosk anticlines occur, whereas in the south; there is the long Safeen anticline that is separated from the Shakrook anticline by a long, wide and hanging Shaqlawa syncline (Fig. 1) (Sissakian and Fouad, 2015). Bartl et al. (2009) conducted a tectonic geomorphological study on the Safeen anticline and concluded that both limbs exhibit different drainage systems. Zebari and Burberry (2013) presented new data about the geometry and evolution of the folds in the IKR. They considered that most of the folds are fault-propagated folds, although some folds are fault-bend folds. The authors adopted their idea, especially the fault-propagated folds. Sissakian and Fouad (2015) updated the geological map of Iraq and modified the Shakrook anticline. Le Garzica et al. (2017) constructed a balanced cross-section (Fig. 2) through a part of the IKR and presented many thrusted anticlines, among them is the Shakrook anticline. They suggested that the Shakrook anticline is thrust over the southerly existing Shaqlawa hanging syncline. The authors have recognized a thrust fault in the extreme northwestern part of the anticline only. Le Garzica et (2017) considered a wide syncline between the Shakrook anticline and the northerly existing Makook anticline (Fig. 2). The authors are not fully in accordance with the constructed cross-section, since there are many anticlines in between the two mentioned anticlines, such as Balisan, Paliwan and Kamosk anticlines (Fig. 3). Ghafur et al. (2019) studied the Aqra anticline that is located NW of the Shakrook anticline and showed that the Aqra anticline is laterally growing. They used different geomorphological and structural indications to confirm the growth of the anticline. The authors have used part of those indications in the current study. Sissakian et al. (2020) performed studies on Zozik, Handreen and Tanoun anticlines, all are northeast of the Shakrook anticline to recognize different geomorphological and structural forms and have used them to confirm the lateral growth of the anticlines, and the anomalous shapes of some of the mentioned anticlines. The current authors have used part of the used geomorphological and structural forms in the current study to indicate the lateral growth of Shakrook anticline. Among those forms are en-echelon plunges, domes, water gaps, abandoned alluvial fans.

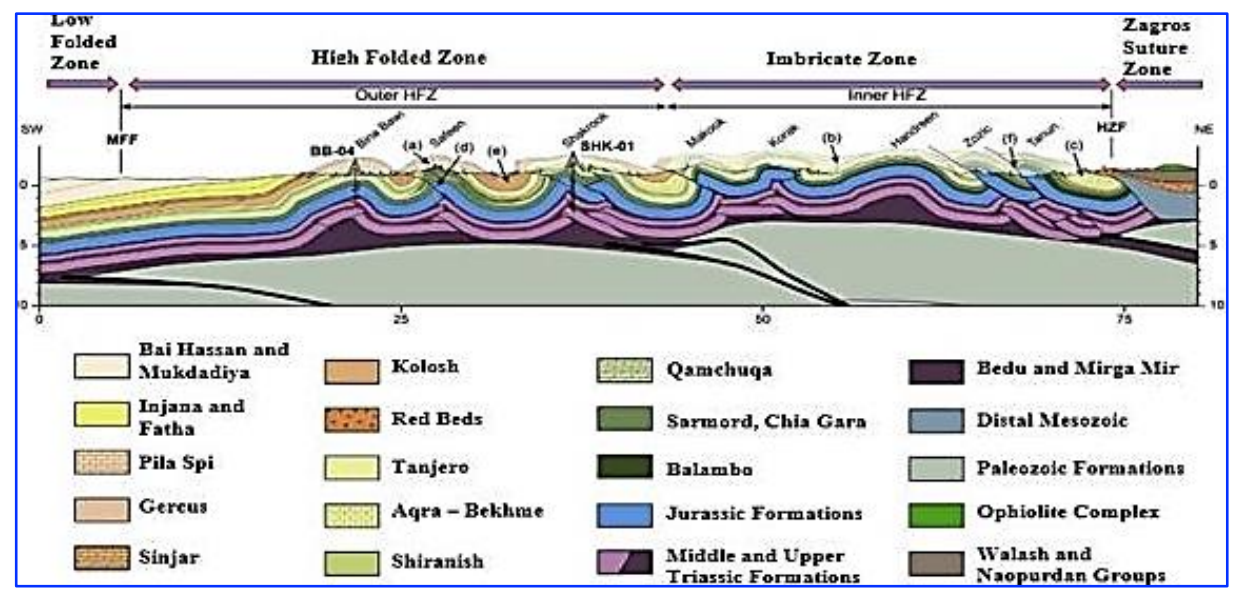

Fig. 2. Balanced section through Safeen anticline and neighboring folds (Le Garzica et al., 2017)

The aim of the current study is to elucidate the details of the Shakrook anticline, as it is a complicated anticline, i.e., more than one simple fold. Furthermore, to identify the structural complexity within Shakrook anticline which is different from what is presented in the existing geological maps of different scales. Also, to indicate whether the Shakrook anticline is laterally growing like some of the surrounding anticlines or otherwise.

\section{Materials and Methods}

The current study was performed by means of using topographical maps at different scales (1:100000 and 1:2500000), tens of published papers and books were reviewed. High-quality satellite 
images were visually interpreted to recognize the details of the Shakrook anticline. Accordingly, a lot of new data were interpreted, which are quite different from those presented in the already existing geological maps (Sissakian and Fouad, 2015). Moreover, we have used the opinions of many researchers to interpret structural and geomorphological forms to update the geology of the Shakrook anticline. Among those researchers are; Campbell (1958), Falcon (1974), Burbank and Pinter (1999), Burbank and Anderson (2001), Keller and Pinter (2002), Ramsey et al. (2008), Foosen (2010), Bretis et al. (2011), Burscher et al. (2012), Zebari and Burberry (2013), and Gurpuz and Saein (2019). Part of the data used by the current authors (Gahfur et al., 2019 and Sissakian et al., 2020) from different neighboring areas of the studied area and along many other anticlines were used in the current study to interpret the existing structural and geomorphological forms along the Shakrook Anticline.

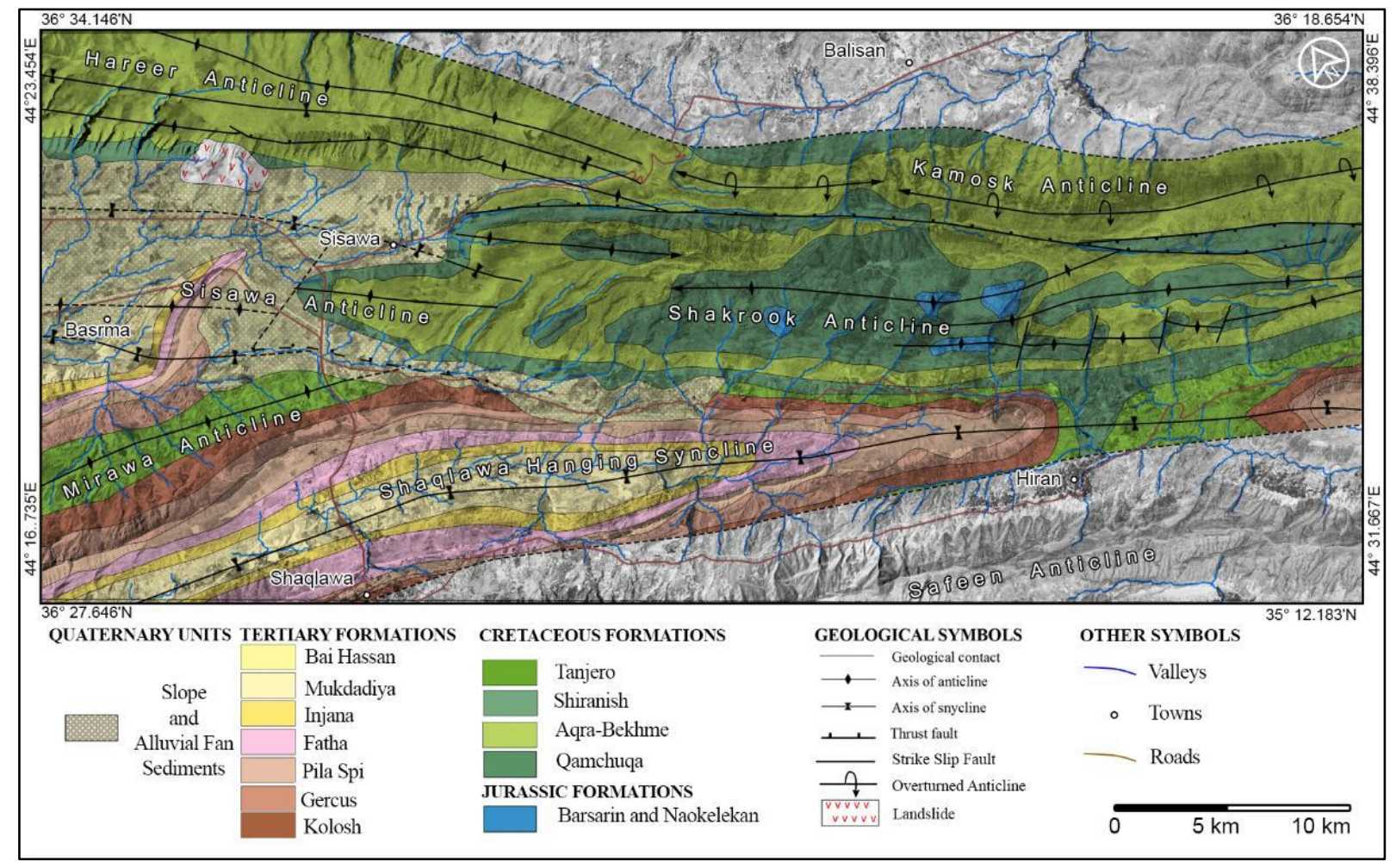

Fig. 3. Geological map of the Shakrook anticline and surrounding area (Modified from Sissakian and Fouad, 2015)

Seven satellite images are presented in the current study to elucidate the interpreted details about structural and geomorphological forms within the Shakrook anticline. The interpreted details cannot be shown on the geological map due to the scale limitations. In some presented images, some of the details are not repeated when they presented on other images that have part overlap, this is done to avoid the complexity of the interpreted data. The used structural symbols in the interpretations of the images are the same as those shown on the geological map. The locations of the satellite images are shown in Fig.1.

\section{Geological Setting}

Three main geological aspects are discussed hereinafter to clearly elucidate the status of the Shakrook anticline. The aspects are geomorphology, tectonics and structural geology, and stratigraphy. The presented data depends mainly on Sissakian et al. (2014), Fouad (2015) and Sissakian and Fouad (2015), and Sissakian and Al-Jibouri (2014). The updated geological is shown in Fig. 3. 


\subsection{Geomorphology}

The Shakrook anticline is located within the High Mountainous Province (Sissakian and Fouad, 2015). The anticline forms a rough topography with steep cliffs and deeply cut valleys. The steep cliffs are mainly due to the anticlinal ridges, and water gaps (Fig. 4). A very special water gap is developed crossing two anticlines, two thrust faults (originally two synclines), and one back thrust fault (extreme left side of the Fig. 4). This is a very rare case; however, other water gaps drain in axial valleys. Those valleys were running along synclinal axes and nowadays they run along thrust faults ( $\mathrm{ThF} 1$ and $\mathrm{ThF} 2$, Fig 4). Many inclined valleys are also developed along the southwestern limb of the Shakrook anticline (Fig. 4). forms are also developed at different parts of the axes of the Shakrook East and Shakrook West anticlines, they usually end with water gaps (Fig. 4). Another rare case is the existence of two successive water gaps (Fig. 5) as it is found in Shakrook East and Biluk anticlines. These are also very rare cases; not developed in the anticlines of the IKR. Flat irons are developed along the northeastern limb of the Shakrook East anticline within the rocks of the Qamchuqa Formation (Fig. 4), and along the Sisawa anticline within the rocks of the Shiranish Formation (Fig. 6).

\subsection{Tectonics and Structural Geology}

The study area is located within the High Folded Zone of Iraq that is a part of the Arabian Plate. The zone belongs to the Outer Platform that is part of the ZFTB (Fouad, 2015). The Shakrook anticline is not a simple fold, it includes two main domes, they are called in the current study the Shakrook East and Shakrook West anticlines. Moreover, at the northwestern plunge of the anticline, there is a small anticline with a clear northwestern plunge that is dissected by a fault (Fig. 6), it is called the Sisawa anticline, in the current study. The southwestern limb of Shakrook anticline includes a long anticline that is called Biluk anticline, it is separated from the Shakrook East anticline by a shallow and wide syncline (Fig. 5). However, its northwestern extension pinches out through the southwestern limb of the Shakrook anticline, as well as southeastern extension of the Sisawa anticline (Fig. 7). The Biluk anticline is dissected by four strike-slip faults with NE - SW trend, the faults also dissect the syncline (Fig. 5). Along the northwestern part of the Shakrook and Sisawa anticlines, there is a thrust fault (Fig. 6), this thrust fault was interpreted by La Garzica et al. (2017). The axes of the Mirawa anticline and the northerly existing syncline are hindered by this thrust fault (Fig. 6). Another fault dissects the axis of the Sisawa anticline (Fig. 6), it is difficult to decide whether this fault dissects the thrust fault or otherwise (Point A, Fig. 6).

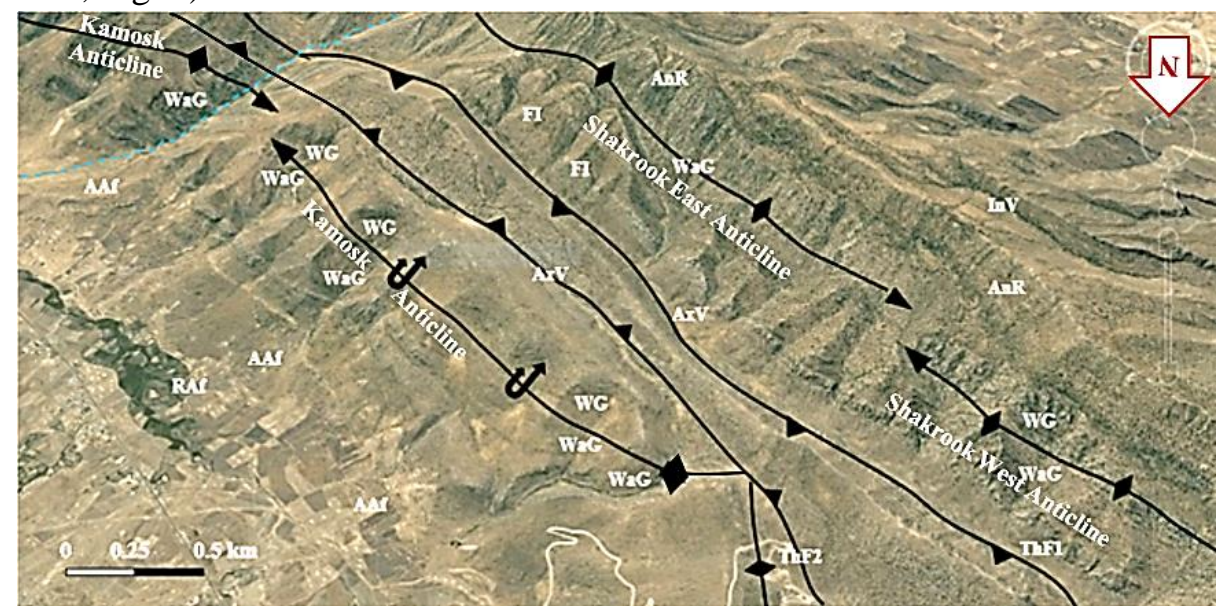

Fig. 4. Satellite image showing Shakrook East, Shakrook West and Kamosk (overturned) anticlines. Note the steep cliffs which form anticlinal ridges (AnR). WG = Wine glass, WaG= Water gap, InV= Inclined valley, $\mathrm{AxV}=\mathrm{Axial}$ valley, $\mathrm{FV}=$ Fork-shaped valley, $\mathrm{AAF}=$ Abandoned alluvial fan, $\mathrm{Raf}=$ Recent alluvial fan, FI= Flat irons, ThF1 and ThF2 are thrust faults. For location, refer to Fig. 1. 


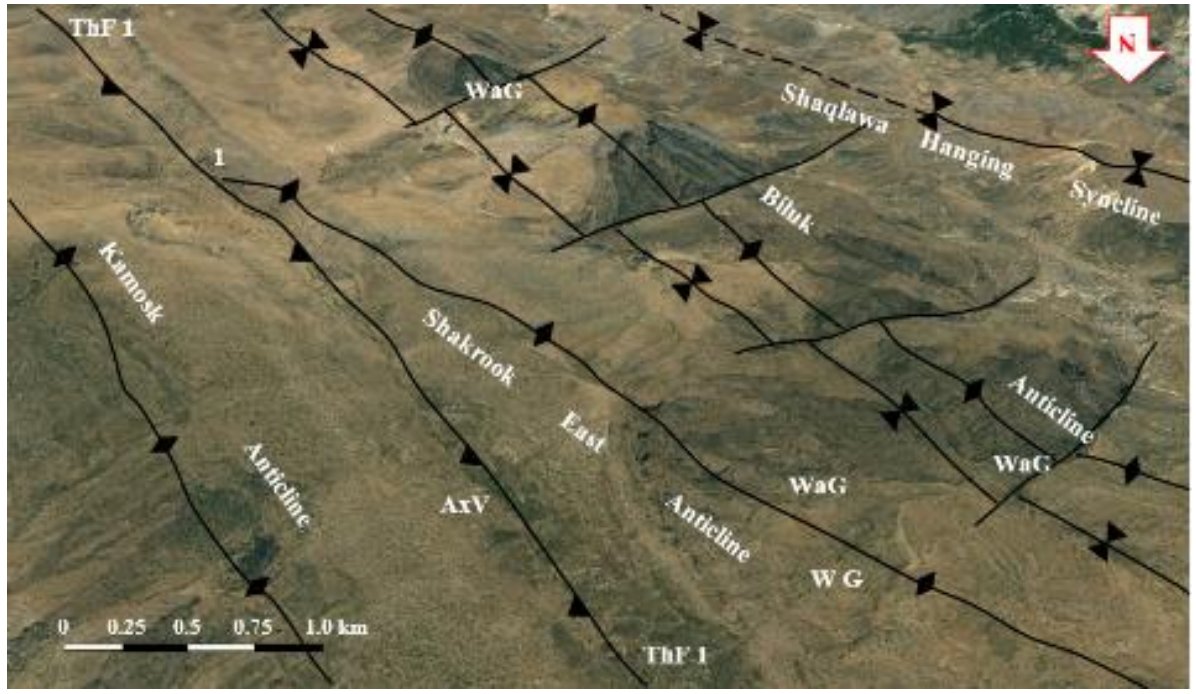

Fig. 5. Satellite image showing the Shakrook East, Biluk and Kamosk anticlines. Not the dissected axis of the Biluk anticline by strike-slip faults. $\mathrm{WaG}=$ Water gap, $\mathrm{WG}=$ Wine glass, $\mathrm{AxV}=$ Axial valley, not the curvatures shapes of the beds along the axes of the Shakrook East and Biluk anticlines. For location, refer to Fig. 1.

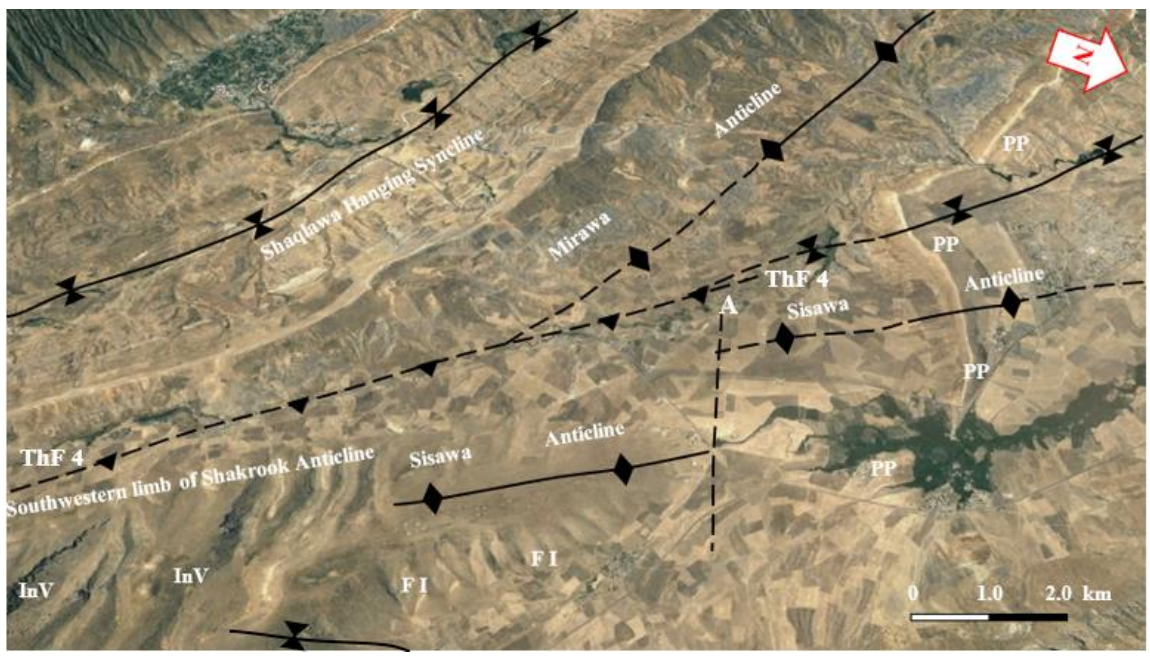

Fig. 6. Satellite image showing complex plunge of Sisawa anticline and the suggested thrust fault. FI= Flat iron, InV= Inclined valley, PP= Pila Spi Formation, A (Refer to the text). For location, refer to Fig. 1.

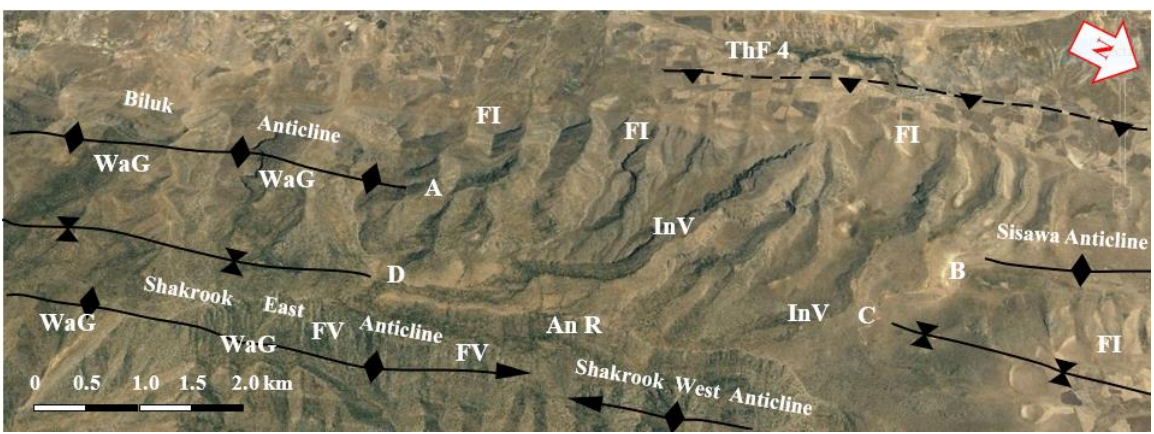

Fig. 7. Satellite image showing the southwestern limb of the Shakrook anticline and the pinch out of Biluk and Sisawa anticlines at points A and B, respectively, and the synclines at point C and D, respectively. FI= Flat iron, $\mathrm{InV}=$ Inclined valley, $\mathrm{FV}=$ Fork-shaped valley, $\mathrm{WaA}=$ Water gap, $\mathrm{AnR}=$ Anticlinal ridge 


\subsection{Stratigraphy}

The exposed formations in the Shakrook anticline are briefed hereinafter depending on Sissakian and Al-Jiburi (2014) and Sissakian and Fouad (2014). Whereas the geological map is shown in Fig. 3.

- Naokelekn Formation (Late Jurassic): The formation consists of laminated shaley limestone, and calcareous shale. The thickness of the formation is about $12 \mathrm{~m}$.

- Barsarin Formation (Late Jurassic): The formation consists of laminated limestone and dolomitic limestone. The exposed thickness of the formation is few meters.

- Qamchuqa Formation (Early Cretaceous): The formation consists of massive limestone, dolomitic limestone and dolomite. The thickness of the formation is about $220 \mathrm{~m}$.

- Bekhme Formation (Late Cretaceous): The formation forms the bulk of Shakrook anticline, it consists of well bedded and thickly bedded dolostone and limestone. The thickness of the formation is about $125 \mathrm{~m}$.

- Shiranish Formation (Late Cretaceous): The formation consists of well bedded white marly limestone, overlain by bluish grey papery marl. The thickness of the formation is about $75 \mathrm{~m}$.

- Tanjero Formation (Late Cretaceous): The formation consists of dark greenish grey fine clastics. The thickness of the formation is $120 \mathrm{~m}$.

- Kolosh Formation (Paleocene): The formation consists of black fine clastics. The thickness of the formation is $100 \mathrm{~m}$.

- Gercus Formation (Eocene): The formation consists of reddish brown fine clastics. The thickness of the formation is $100 \mathrm{~m}$.

- Pila Spi Formation (Late Eocene): The formation consists of well bedded dolostone and limestone with rare marl beds. The thickness of the formation is $15 \mathrm{~m}$.

- Fatha Formation (Middle Miocene): The formation consists of thick reddish-brown claystone with thin limestone and very rare gypsum. The thickness is $110 \mathrm{~m}$.

- Injana Formation (Late Miocene): The formation consists of thick reddish brown-claystone and sandstone in a cyclic nature. The thickness is $130 \mathrm{~m}$.

- Mukdadiya Formation (Late Miocene - Pliocene): The formation consists of thick grey claystone and sandstone in a cyclic nature. The thickness is $340 \mathrm{~m}$.

- Bai Hassan Formation (Pliocene - Pleistocene): The formation consists of thick brown claystone and conglomerate in a cyclic nature. The thickness is $500 \mathrm{~m}$.

- Quaternary Sediments: These sediments are poorly developed and include alluvial fans sediments (both old and recent), slope sediments, and valley fill sediments.

\section{Results}

From reviewing of the geological maps, interpretation of satellite images and field investigations, the Shakrook anticline was found to consists of two long domes with en-echelon plunge (Fig. 4). Therefore, it is called in the current study as Shakrook East and Shakrook West anticlines. However, when the whole anticline is considered, then it will be called as Shakrook anticline. The following results were achieved.

\subsection{Northwestern Plunge of the Shakrook Anticline}

The northwestern plunge of the Shakrook anticline was presented on geological maps as a normal plunge (Sissakian and Fouad, 2015). After thorough interpretations and field investigation, it has been found that it is a very complicated plunge. There is a separate anticline that is called in the current study as the Sisawa anticline (Fig. 8), the axis is dissected by a strike slip fault (Points 2-3, Fig. 8). The trend of the fault was suggested to be $\mathrm{NE}-\mathrm{SW}$, which is a common trend of many faults in the neighboring 
area, besides the three interpreted lineaments (Point 8, Fig. 8) along the southwestern limb of the Sisawa anticline. The northwestern plunge of the Sisawa anticline is clear from the ridge formed by the rocks of the Pila Spi Formation ( Fig. 8), and the curvature of the stream that flows from many springs at Sisawa village (Fig. 8). However, there is no southeastern plunge, the anticline pinches out within the southwestern limb of the Shakrook anticline (Point 7, Fig. 8). A long syncline exists between the Sisawa and Shakrook anticlines with a clear plunge towards southeast (Point 6, Fig. 8). The extension of the syncline northwest ward is not clear because it is covered by the Quaternary sediments (Figs. 3 and 8); moreover, it is very difficult to decide whether the axis of the syncline is dissected by the strike-slip fault (Points $2-3$, Fig. 8) or otherwise. The axis of the syncline; however, is more likely extending northwest wards, this assumption is based on the presence of the outcrops of the Pila Spi Formation (PP near the Point 9, Fig.8) along the northeastern limb of the Sisawa anticlines. The northwestern plunge of the Shakrook West anticline is a normal plunge (Fig. 8). However, due to the existence of a long thrust fault (ThF 1, Fig. 8) that has hindered part of the northeastern limb of the anticline, the plunge exhibits an abnormal shape (Fig. 8).

\subsection{Southeastern Plunge of the Shakrook Anticline}

The axis of the Shakrook anticline at its southeastern end is truncated by a long thrust fault (ThF 1, Fig. 5). The axis of the anticline, however, before the thrust fault bends northeast wards (Point 1, Fig. 5). More southeast wards, the axis of the Shakrook East anticline appears again and continues southeast wards until the anticline pinches out (Fig. 9).

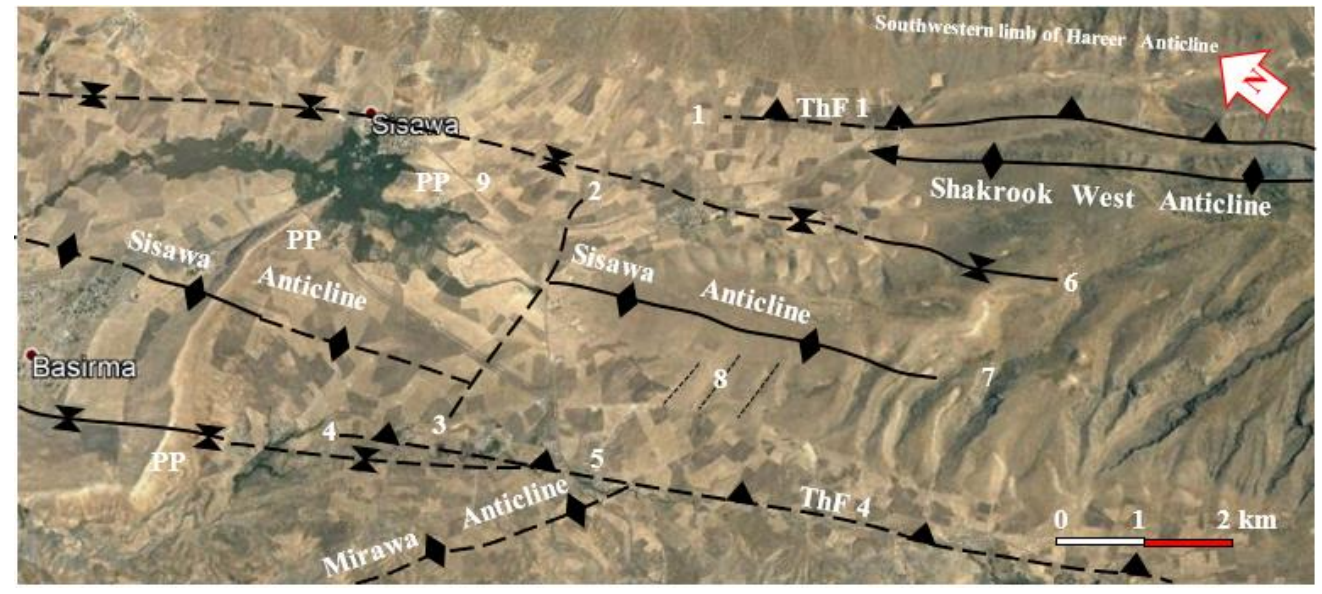

Fig. 8. Satellite image showing the Sisawa and Shakrook West anticlines. ThF 1 and ThF4, are main thrust faults, $\mathrm{PP}=$ Pila Spi Formation. For indicating the numbers, refer to the text. For location, refer to Fig. 1

\subsection{Southwestern Limb of the Shakrook Anticline}

The southwestern limb of the Shakrook anticline is also complicated like the northwestern plunge. At the northwestern part of the limb, the Sisawa anticline pinches out southeast wards within the limb (Fig. 8), whereas at the southeastern part of the limb, the Biluk anticline pinches out northwest words (Fig. 7). It is worth mentioning that the Biluk anticline extends southeast wards as a separate anticline separated by a clear syncline from the Shakrook anticline (Figs. 5 and 9).

\subsection{Northeastern Limb of the Shakrook Anticline}

The northeastern limb of the Shakrook anticline starts with a long thrust fault (ThF 1, Fig. 8) that runs almost parallel to the anticlinal axis. The thrust faults ThF 1 and ThF 2 (Fig. 10) has hindered the 
syncline between the Shakrook and Kamosk anticlines. Therefore, the northeastern limb of the Shakrook anticline can be hardly distinguished from the southwestern limb of the Kamosk anticline.

\subsection{Faults}

Different types of faults were interpreted in the current study, most of them were not presented in the geological map (Sissakian and Fouad, 2015). The existing faults are briefed hereinafter.

\subsubsection{Thrust Faults}

Four main thrust faults exist within the studied area, these are called ThF 1, ThF 2 , ThF 3 and ThF 4 (Figs, 4, 5, 6, 7, 8, 9 and 10). Thrust faults (ThF 2 and ThF 4) were interpreted for the first time in the current study and presented on the geological map and the enclosed satellite iamges, whereas the other two thrust faults were more precisely located on the images and the updated geological map (Fig. 3).

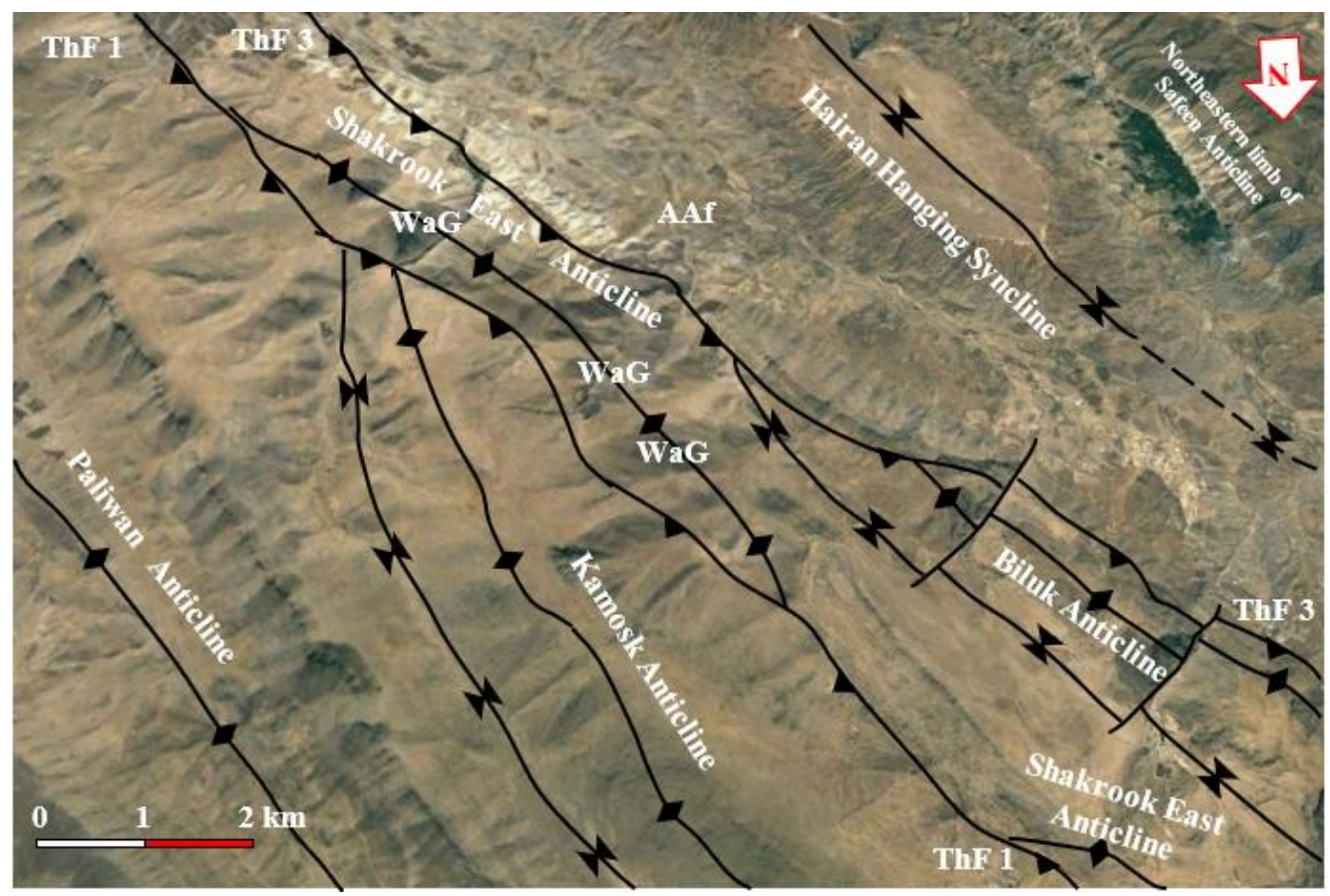

Fig. 9. Satellite image showing the southeastern end of the Shakrook anticline. Note the complex structural forms on both limbs of the Shakrook East anticline. $\mathrm{WaG}=$ Water gap, AAf= Abandoned alluvial fan. For location, refer to Fig. 1

\subsubsection{Strike-Slip Faults}

Many strike-slip faults were interpreted and presented in the current study, especially along the Biluk anticline (Figs. 5 and 9). One long strike-slip fault was interpreted that dissects the axis of the Sisawa anticline (Figs. 6 and 8). All strike-slip faults have almost NE - SW trend.

\subsection{Geomorphological Forms}

Different geomorphological forms were interpreted from the satellite images at different places within the studied area; all of them are good indications for the lateral growth of an anticline (Keller and Pinter, 2002, Ramsey et al., 2008). The following geomorphological forms were interpreted: Water gaps (Figs. 4, 9 and 10), Abandoned alluvial fans (Figs. 4, 9 and 10), Axial valleys (Figs. 4 and 10), Inclined valleys (Figs. 4, 7 and 10), moreover other geomorphological forms were interpreted; like Flat irons (Fig. 6 and 7) and Anticlinal ridges (Fig. 4 and 7). 


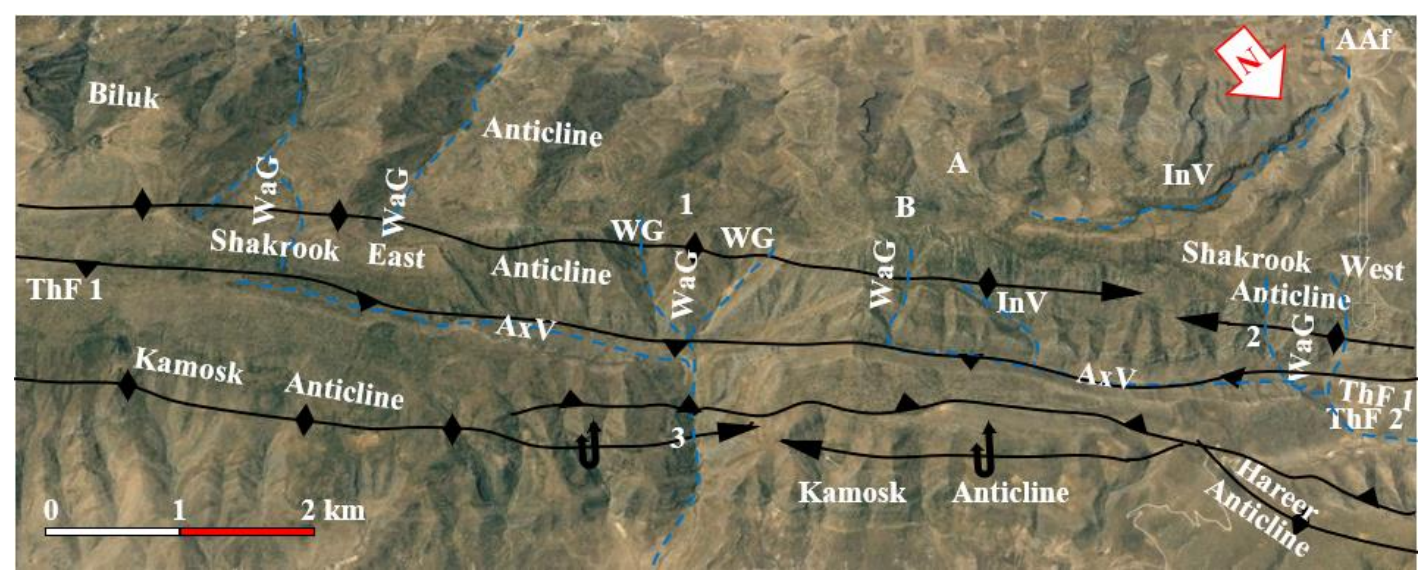

Fig. 10. Satellite image showing the Shakrook anticline with details of both limbs. Note the pinching out of Biluk anticline within the southwestern limb of the Shakrook anticline at point A. WaG= Water gap, $\mathrm{WG}=$ Wine glass, $\mathrm{InV}=$ Inclined valley, $\mathrm{AxV}=$ Axial valley, AAf=Abandoned alluvial fan. For location, refer to Fig. 1

The following geomorphological forms were interpreted: Water gaps (Figs. 4, 9 and 10), Abandoned alluvial fans (Figs. 4, 9 and 10), Axial valleys (Figs. 4 and 10), Inclined valleys (Figs. 4, 7 and 10), moreover other geomorphological forms were interpreted; like Flat irons (Fig. 6 and 7) and Anticlinal ridges (Fig. 4 and 7). It is worth mentioning that in many images, different geomorphological forms exist, but were not marked to avoid the complexity of the interpreted data, and even at the same image, not all forms (of one type) were marked; for the same reason.

\section{Discussion}

\subsection{Complexity of the Shakrook Anticline}

The Shakrook anticline has a very complex structure shown from the presented data. This is attributed to:

- Thrust Fault (ThF 1): The thrust fault (ThF 1) runs almost parallel to the axis of the anticline causing hindering part of the northeastern limb (Figs. 4 and11) and part of the axis (Fig. 5), and the appearance of the axis at the southeastern part (Fig. 9).

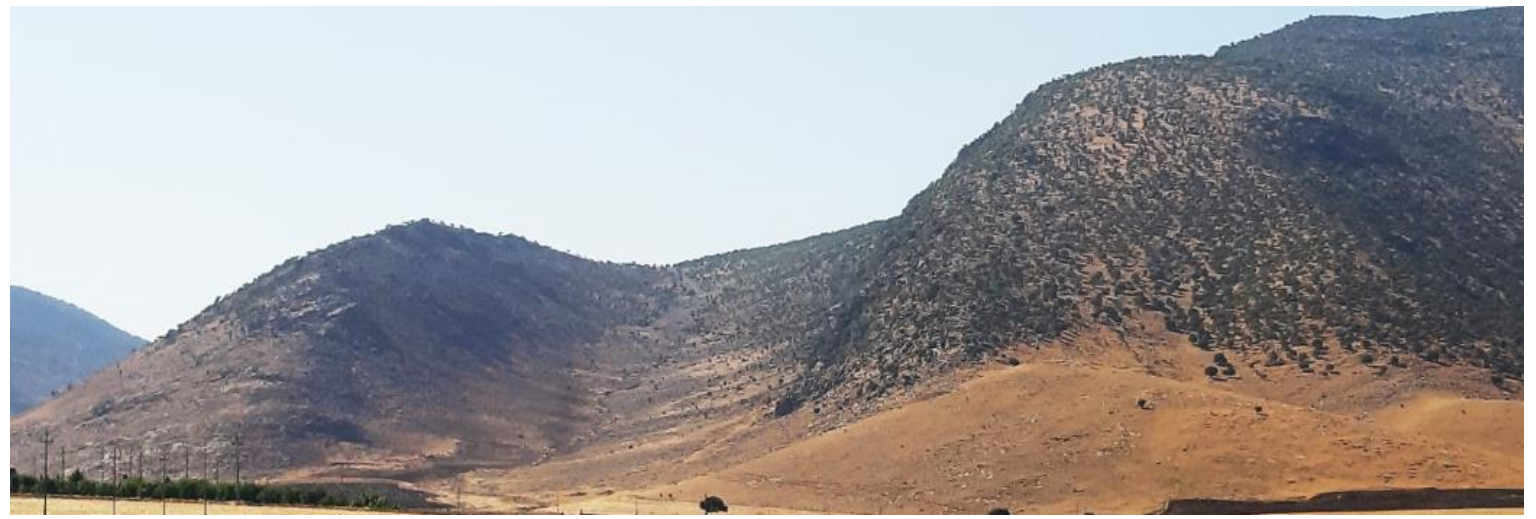

Fig. 11. Thrust fault ThF1 (the left side of the valley)

- Sisawa Anticline: The Sisawa anticline exists along the southwestern limb of the Shakrook anticline (Figs. 6, 7 and 8). The anticline at the southeastern end pinches out (without plunging) along the southwestern limb of the Shakrook anticline (Point 7, Fig. 8 and Fig. 12), whereas the north-easterly syncline pinches out with a clear plunge (Point 6, Fig. 8 and 11). The axis of the Sisawa anticline is 
dissected by a strike slip-fault. The authors have supposed the location of the fault that is covered by the Quaternary sediments based on: i) The end of the exposures of the Shiranish Formation (Fig. 3), and ii) the presence of large spring (Figs. 6 and 8). The orientation of the fault; however, is suggested based on the strike-slip faults present along the Biluk anticline (Figs. 5 and 9), and the existing lineaments along the southwestern limb of the Sisawa anticline (Point 8, Fig. 8). Whereas the extension of the fault is supposed to be at the Points 2 and 3 (Fig. 8).

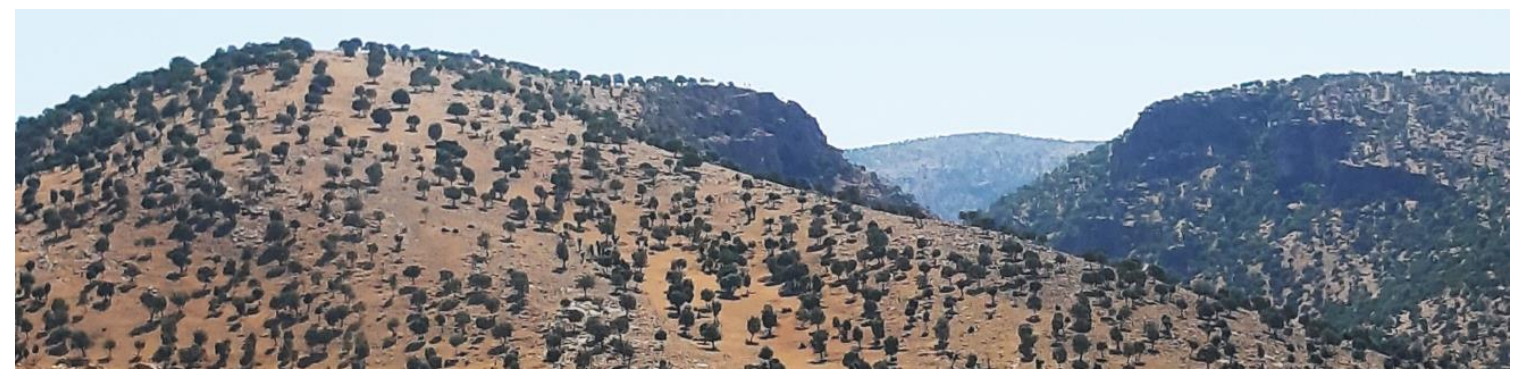

Fig. 12. Pinching out of the Sisawa anticline in the southwestern limb of the Shakrook anticline

- Biluk Anticline: The presence of the Biluk anticline along the southwestern limb of the Shakrook anticline (Figs. 3, 5, 7, 9, 10 and 13). The northwestern part of the anticline pinches out (without plunging) within the southwestern limb of the Shakrook anticline (Point A, Fig.7), whereas the northwesterly syncline pinches out along the limb at the Point B (Fig. 7). The southeastern part of the Biluk anticlines is hindered by the thrust fault (ThF 3, Fig. 9).

- Kamosk Anticline: The Kamosk anticline exists along the northeastern limb of the Shakrook anticline (Figs. 3, 4, 5, 9, 10 and 14). It is an overturned anticline (Figs. 4 and 10); moreover, its southwestern limb is locally over-thrusted (by the thrust fault ThF 2, Fig. 4) by the northeastern limb of the Shakrook anticline (Figs. 5, 9 and 10). The thrusted parts of the Shakrook anticline over the Kamosk anticline have hindered the existing syncline in between; therefore, it looks like one limb of the Shakrook anticline.

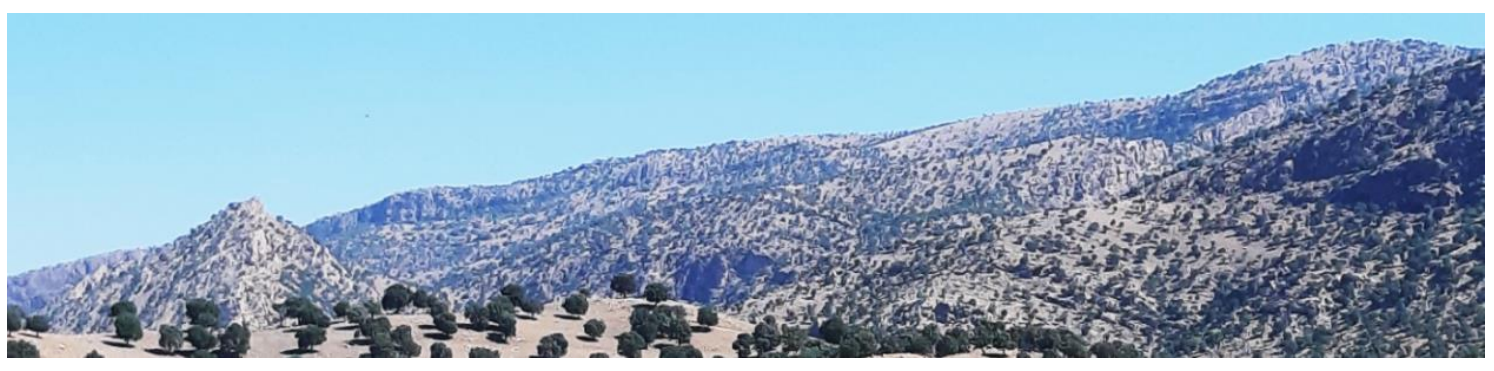

Fig. 13. The Biluk anticline (foreground) along the southwestern limb of the Shakrook anticline (background)

- Thrust Fault (ThF 2): The thrust fault ThF2 is a long fault and has thrusted the Shakrook anticline on the Hareer and Kamosk anticlines (Fig. 15), it was not mapped previously. The syncline between the Hareer and Shakrook anticlines, and the syncline between the Kamosk and Shakrook anticlines are partially or totally (respectively) covered by this thrust fault. This thrust fault has caused complications in the northeastern limb of the Shakrook anticline and many researchers have not recognized the presence of the Kamosk anticline. 


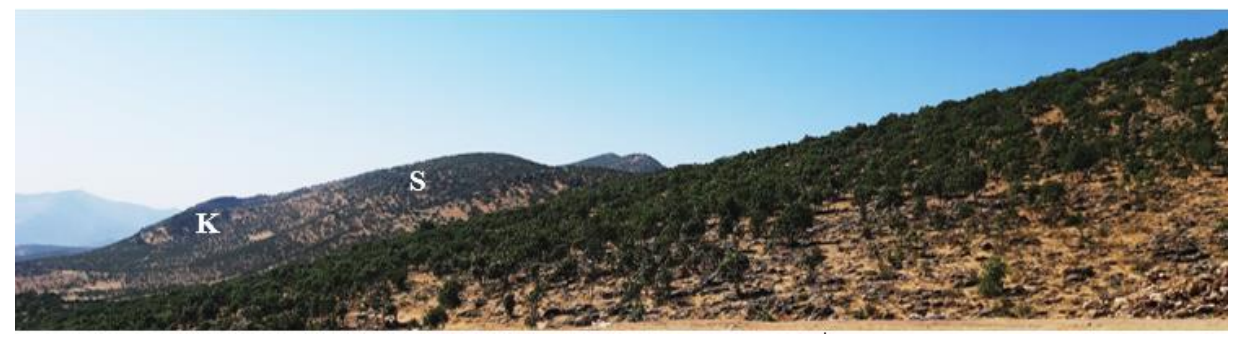

Fig. 14. The Kamosk (K) overturned anticline thrusted over the Shakrook anticline (S)

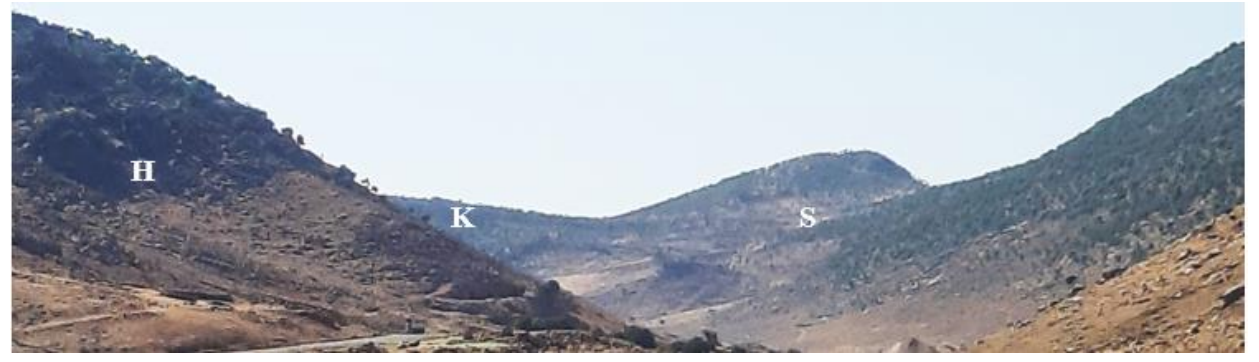

Fig. 15. Thrust fault ThF2 runs along the valley between the Hareer $(\mathrm{H})$, Kamosk $(\mathrm{K})$ and Shakrook anticlines.

- Thrust Fault (ThF 3): This thrust fault has affected the southwestern limb of the Shakrook anticline, where the Biluk anticline occurs. The thrust fault has caused partial disappearance of the southwestern limb of Biluk anticline leaving the northeastern limb only (Fig. 16).

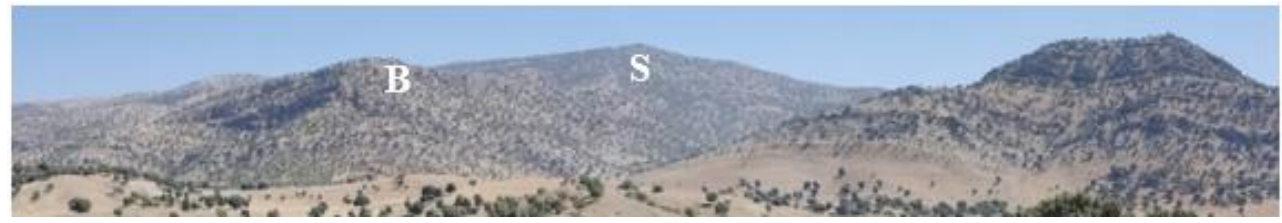

Fig. 16. Thrust fault ThF 3. Note the disappearance of the southwestern limb of the Biluk anticline (B), Shakrook anticline (S) appears in the background.

- Thrust Fault (ThF 4): Although this thrust fault was detected by La Garzica et al. (2017) (Fig. 2); however, in the current study, the extension of the fault is quite different. The thrust fault has not affected the shape and complexity of the Shakrook anticline; however, it has affected the Sisawa anticline and the south-westerly existing Mirawa anticline and the existing syncline in between them (Figs. 6 and 8). Because the whole area is covered by different types of Quaternary sediments, it is very difficult to indicate the precise location of the thrust fault. The authors have considered the location of the thrust fault to be at the last extension of the axis of the Mirawa anticline (Points 4 and 5 at Fig. 8) and the northerly existing synclinal axis (Figs. 6 and 8). Whereas the orientation of the thrust fault is based on the orientation of the other thrust faults. It is very difficult to indicate whether the strike-slip fault has dissected the thrust fault (Point 3, Fig. 8) or otherwise, because the whole area is covered by the Quaternary sediments.

- Syncline between Shakrook and Sisawa anticlines: Most of this syncline is covered by different types of Quaternary sediments (Fig. 8); however, the southeastern plunge area is very clear (Fig. 17). The authors have considered that the syncline is not affected by the strike-slip fault that dissects the axis of the Sisawa anticline, this assumption is based on the presence of few outcrops of the Pila Spi Formation, which indicate the location of the syncline (Points 2 and 9, Fig. 8). If the synclinal axis was dissected by the strike-slip fault, then the outcrops of the Pila Spi Formation 
would not be at the existing location. The authors have extended the synclinal axis; although the whole area is covered by the Quaternary sediments because there should be a syncline between the Hareer and Sisawa anticlines (Fig. 8).

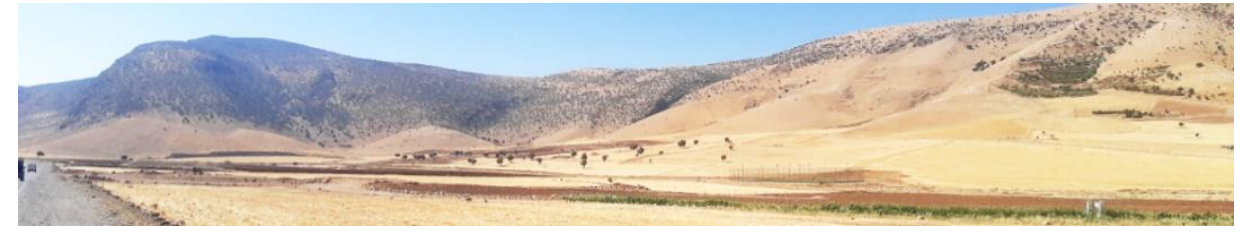

Fig.17. The southeastern plunge of the syncline between the Shakrook (on the left) and Sisawa (on the right) anticlines. Note that in the foreground the whole area is covered by Quaternary sediments

\subsection{Faults}

The authors believe that the thrust faults (ThF 1, ThF 2 and ThF 3) have the same age that is contemporaneous with the folding. This assumption is based on the type of the Shakrook anticline that is most probably a fault-propagated fold as the data shown on the constructed cross section (La Garzica et al., 2017) (Fig. 2) explains this type of folding and also the constructed seismic cross section by Zebari (2003) (Fig. 19). Whereas the thrust fault (ThF 4) can be of different age; however, the authors believe that it is more likely to has the same age as the other thrust faults, but with less amplitude. This assumption is based on the type of the involved rocks in the thrust fault. The rocks are clastics of the Tanjero, Kolosh and Gercus formations; therefore, the attenuation of the forces exerted due to the collision of the Arabian and Eurasian plates will be shallower, which means the detachment (decollement) was most probably over the hard rocks of the Bekhme Formation (Upper Cretaceous age). Accordingly, the soft clastics rocks along the southwestern limb of the Shakrook anticline are thrusted over the same rocks along the northeastern limb of the Shaqlawa hanging syncline. The thrust fault ThF4 is shorter than the other thrust faults, it terminates few kilometres east of the end of the Sisawa anticline and where the stratigraphic succession becomes normal (Fig. 18). The strike-slip faults are younger than the thrust faults because one of them has dissected the thrust fault ThF 3 (Fig. 9). The authors believe that the strike slip faults (sinistral type) are formed by contractional faults during the continuous growth of Shakrook and Biluk anticlines, the accumulated shear stresses have caused the strike-slip faults. It is worth to mention that contractional deformation structures form when rocks are shortened by tectonic forces, this deformation can affect all parts of collision zones (Fossen, 2010).

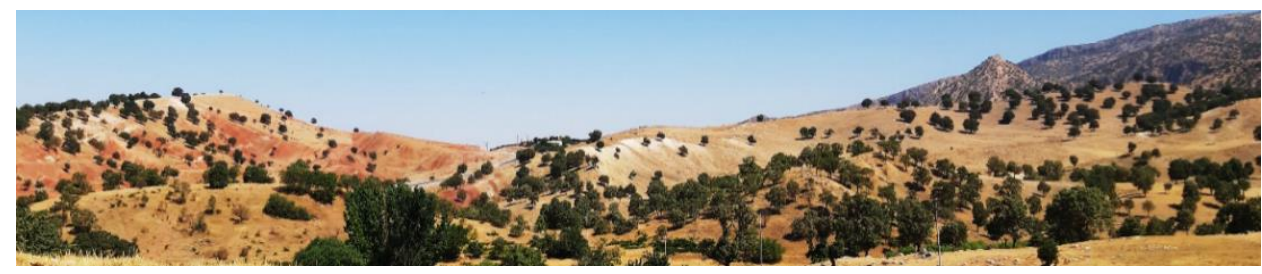

Fig. 18. Normal stratigraphic succession between the Shakrook anticline (on the right) and the Shaqlawa Hanging syncline (on the left).

\subsection{Domes and En-echelon Plunges}

The Shakrook anticline exhibits two large domes with en-echelon plunges (Figs. 7 and 10). Both features are good indications for the lateral growth of the Shakrook anticline (Campbell, 1958, Fossen, 2010 and Bretis et al., 2011). The Shakrook East anticline forms left-hand en-echelon plunge with the Shakrook West anticline, whereas the Shakrook West anticline forms right-hand en-echelon plunge with the Sisawa anticline, which according to Campbell (1958) can be considered as an embryo dome that usually separate from the main fold due to the lateral growth of the main fold. 


\subsection{Geomorphological Forms}

The most significant recognized geomorphological forms in the Shakrook anticline are the water gaps. Very special forms of water gaps were observed on both sides of the axial part of the anticline, some of them drain northwards and others southwards (Fig. 10). This is attributed to the change in the asymmetry of the anticline and the presence of the long thrust fault that has hindered the syncline between the Shakrook and Kamosk anticlines (ThF1, Fig. 10). Moreover, some of the water gaps are accompanied with wine glass forms (Point 1, Fig. 10) others are just deeply cut small valleys (Point 2, Fig. 10), and those developed along the Shakrook East and Biluk anticlines (Fig. 5). Another rare water gap was observed along the axis of the Shakrook East anticline, where two water gaps merge in one valley, and the valley dissects the northerly existing Kamosk anticline forming another water gap (Point 3, Fig. 10). This rare case was formed due to the presence of two thrust faults (ThF 1 and Th 2, Fig. 10); otherwise, the water gap will end; usually, merging with a main stream and/ or valley that runs along the synclinal axis or flowing parallel to the main ridge along which the water gap has developed. Other recognized geomorphological forms within the studied area indicate the lateral growth of the Shakrook anticline. Those forms are: Inclined valleys (Figs. 4 and 7), Axial valleys (Figs. 4 and 5), Fork-shaped valleys (Figs. 4 and 7), Abandoned alluvial fans (Figs. 4) (Keller and Pinter, 2002; Ramsey et al., 2008).

\subsection{Subsurface Form of the Shakrook Anticline}

To discuss the subsurface form of the Shakrook anticline, we have used the interpretation of a seismic line by Zebari (2003) (Fig. 19). Only two thrust faults were interpreted by Zebari (2003) and the one in the left is the same which we have mapped between the Shakrook and Kamosk anticlines (ThF 2) (Figs. 3, 4, 5, 9, 10 and 15). Sissakian and Fouad (2015) have also mapped a thrust fault (ThF 1) but in the opposite direction as we have interpreted in the current study, however, this thrust fault is not shown by Zebari (2003) in Fig. 19. For the second interpreted fault (the southwestern thrust fault, Fig. 19); we cannot decide exactly which of our interpreted thrust faults it coincides with ThF 3 or ThF 4. But, most likely it is the thrust fault ThF 4, where the southwestern limb of the Shakrook anticline is thrusted over the northeastern limb of the Shaqlawa hanging syncline. Moreover, the interpretation of Zebari (2003) contradicts with our interpretation about the decollement for the thrust fault ThF 4 that was along the Upper Cretaceous Bekhme Formation., whereas he suggested the decollument to be along rocks older than the Triassic rocks (Fig. 19).

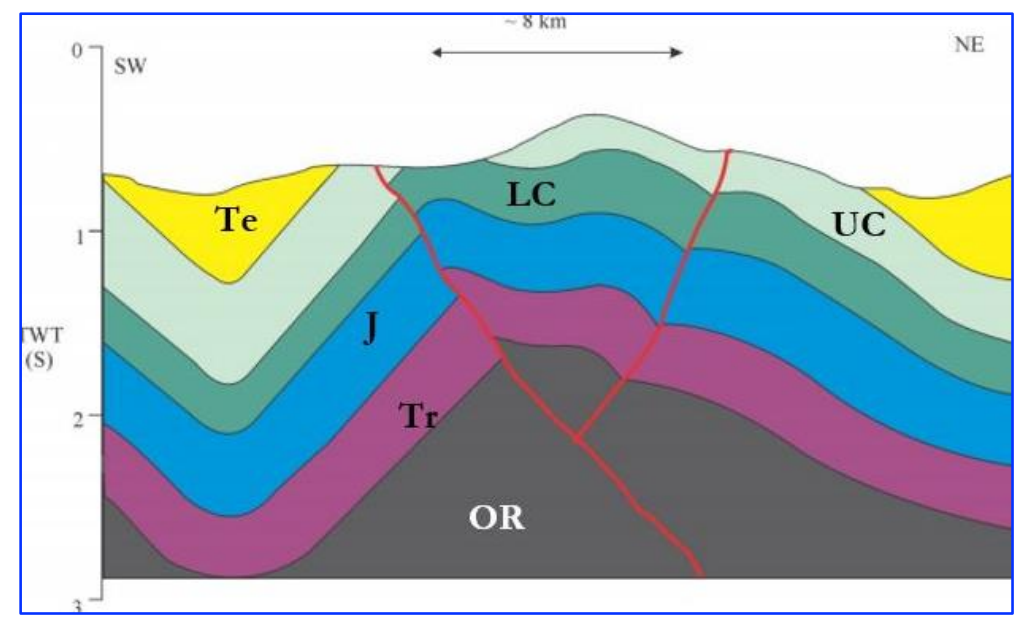

Fig.19. Seismic cross section across the western side of the Shakrook anticline (after Zebari, 2003, the seismic line is after Petroceltic, 2013 in Zebari 2003). Note that in the current study this part of the anticline is called Sisawa anticline. $\mathrm{OR}=$ Rocks older than Triassic, $\mathrm{Tr}=$ Triassic rocks, J= Jurassic rocks, $\mathrm{LC}=$ Lower Cretaceous rocks, $\mathrm{UC}=$ Upper Cretaceous rocks, $\mathrm{Te}=$ Tertiary rocks 


\section{Conclusions}

The following can be concluded from the current study: The Shakrook anticline has a very complex structural form consisting of two main domes arranged in an en-echelon plunge. An embryo fold called the Sisawa anticline (in the current study) is developed at the northwestern plunge of the Shakrook anticline. Four thrust faults were developed along the Shakrook anticline, all have almost the same trend of the main fold. The thrust faults have hindered the existing synclines (partially or totally) on both sides of the Shakrook anticline. Along the southwestern limb of the Shakrook anticline, two folds were developed. In the southeastern part, the Biluk anticline and in the northwestern part the Sisawa anticline. The thrusting of the Shakrook anticline over the southwestern limb of the Kamosk anticline has formed a complex structural form, some of the beds along the Kamosk anticline are overturned that has increased the structural complexity of the Shakrook anticline and seem as the northeastern limb of the Shakrook anticline. Hareer anticline is also thrust over the Shakrook anticline causing hindering of the synclinal axis in between them. Many strike-slip faults occur along the Shakrook anticline, they all have $\mathrm{NE}-\mathrm{SW}$ trend and are younger than the four thrust faults.

\section{Acknowledgements}

The authors would like to express thanks to the authorities of the University of Kurdistan Helwer for providing field car during the field investigations. The authors are grateful to the Editor in Chief Prof. Dr. Salih M. Awadh, the Secretary of Journal Mr. Samir R. Hijab and the Technical Editors for their great efforts and valuable comments.

\section{References}

Alavi, M., 2004. Regional stratigraphy of the Zagros Fold-Thrust Belt of Iran and its proforeland evolution. American Journal Science, 304, 1 - 20.

Allen, M., Jackson, J. and Walker, R., 2004. Late Cenozoic reorganisation of the Arabia -Eurasia collision and the comparison of short-term and long-term deformation rates. Tectonics, 23, TC2008.

Al-Qayim, B., Omer, A. and Koyi, H., 2012. Tectonostratigraphic overview of the Zagros Suture Zone, Kurdistan Region, Northeast Iraq. GeoArabia, 17 (4), 109-156.

Bartl, N., Grasemann, B., Faber, R. and Lockhart, D., 2009. Tectonic geomorphology of the Safeen Anticline (Northern Iraq), EGU General Assembly held 19-24 April 2009 in Vienna, Austria, 7626.

Bennett, E., Youngson, J., Jackson, j., Norris, R., Raisbeck, G., Yiou, F. and Fielding, E., 2005. Growth of south rough ridge, Central Otago, New Zealand: using in situ cosmogenic isotopes and geomorphology to study an active, blind reverse fault. Journal Geophysics Researches, 110, B02404.

Berberian, M., 1993. Tectonic Map of Iran scale 1:1500000. In book: Continental Deformation in the Iranian Plateau, Contribution to the Seismotectonics of Iran, part IV, Publisher: Geological Survey Iran, 52.

Berberian, M. and King, G., 1981. Toward a paleogeography and tectonic evolution of Iran. Canadian Journal Earth Sciences, 18, 210-265.

Blanc, E. J. P., Allen, M.B., Inger, S. and Hassani, H., 2003. Structural styles in the Zagros simple folded zone, Iran. Journal Geological Society London, 160, 401- 412.

Bretis, B., N. Bartl, and B. Graseman, 2011. Lateral fold growth and linkage in the Zagros fold and thrust belt (Kurdistan, NE Iraq). Basin Research, 23, 615 -630.

Burbank, D.W. and Pinter, N., 1999. Landscape Evolution: The Interactions of Tectonics and Surface Processes. Basin Research, 11, 1-6.

Burbank, D.W., Anderson, R.S., 2001. Tectonic Geomorphology. Blackwell Scientific Publications, Oxford, 274 pp.

Campbell, J. D., 1958. En-echelon Folding. Economic Geology, 53, 448 - 472.

Falcon, N.L., 1974. Morpho-tectonic study of Zagros structural belt of SW Iran. Geographic Journal,140 (2), 284291.

Fossen, H., 2010. Structural Geology. Cambridge University Press, 463 pp. 
Fouad, S. F., 2015. Tectonic map of Iraq, 3rd edition, scale 1: 1000000. Iraqi Bulletin of Geology and Mining, 11(1), 1-8.

Ghafur, A. A., Sissakian, V. K., Abdulhaq, H. A. and Omer H. O., 2019. Aqra Anticline: A growing structure in the Iraqi Kurdistan Region. Scientific Journal Koya University, 7 (2), 27-33.

Gurpuz, A. and Saein, A., 2019. Chapter 8, Tectonic Geomorphology of the Zagros Orogen. Developments in Structural Geology and Tectonics, 3, 131-144.

Jassim, S.Z. and Goff, J.C., 2006. Geology of Iraq. Dolin, Prague and Moravian Museum, Brno.

Keller, E.A. and Pinter N., 2002. Active tectonics: Earthquakes, uplift, and landscape, 2nd edition. Prentice Hall, Upper Saddle River, New Jersey, 359 pp.

Le Garzica, E, Vergésb, J., Sapinc, F., Saurab, E., Meressec, F., Ringenbachc, J.C. and Libal , A., 2017. Evolution of the NW Zagros Fold-and-Thrust Belt in Kurdistan Region of Iraq from balanced and restored crustalscale sections and forward modeling. Journal Structural Geology, 124, 51-69.

Ramsey, L.A, Walker, R.T. and Jackson, J., 2008. Fold evolution and drainage development in the Zagros Mountains of Fars Province, SE Iran. Basin Research, 20, 23-48.

Şengör, A.M.C. and Kidd, W.S.F., 1979. Post-collisional tectonics of the Turkish-Iranian plateau and a comparison with Tibet. Tectonophysics, 55 (3-4), 361-376.

Sepher, M, and Cosgrove, J.W., 2004. Structural framework of the Zagros Fold-Thrust Belt, Iran. Marine and Petroleum Geology, 21, 829-843.

Sissakian, V.K. and Al-Jibouri, B.M., 2014. Stratigraphy: In Geology of the High Folded Zone. Iraqi Bulletin Geology Mining., 6, 73-161.

Sissakian, V.K. and Fouad, S.F., 2015. Geological Map of Iraq, 4th edition, scale 1: 1000000. Iraqi Bulletin of Geology and Mining, 11, (1), 9-18.

Sissakian, V.K., Kadhim, T.H. and Abdul Jab'bar, M.F., 2014. Geomorphology of the High Folded Zone. Iraqi Bulletin Geology Mining, 6, 7- 56.

Sissakian, V. K., Abdulhaq, H. A., Ghafur, A. A. and Omer, H. O., 2020. Deducing the lateral growth of Handreen, Zozik and Tanoun Anticlines, Iraqi Kurdistan Region, using geomorphological features. Iraqi Geological. Journal, 53 (1), 1-20.

Stoneley, R., 1981. The geology of the Kuhe Dalneshin area of southern Iran, and its bearing on the evolution of southern Tethys. Journal Geological Society. London, 138, 509- 526.

Zebari, M., 2003. Geometry and Evolution of Fold Structures within the High Folded Zone: Zagros Fold-Thrust Belt, Kurdistan Region-Iraq. Dissertation and Thesis in Earth and Atmospheric Sciences, University of Nebraska, Lincoln, 91pp.

Zebari, M. and Burberry, C.M., 2013. Geometry and Evolution of Fold Structures within the High Folded Zone: Zagros Fold-Thrust Belt, Kurdistan Region-Iraq.Conference paper: Geological Society of America, Abstracts with Programs At: Denver, 45. 